\title{
correspondence
}

\section{Ecdysteroids: \\ a new generic term}

$\mathrm{S}_{\mathrm{IR}},-$ Following the isolation from plant and insect sources of steroids with molting hormone activity in insects, the term ecdysone originally given to one defined compound (1) was used by many authors as a generic term for all substances with molting hormone activity. We feel that it is highly undesirable to use the same name as a generic term and simultaneously as the name for a specific compound. We therefore propose the term 'ecdysteroid(s)' as a generic term for all compounds structurally related to ecdysone. The name is coined in analogy to corticosteroids, a well known generic term comprising steroid hormones from the adrenal cortex.

Since many steroids with molting hormone activity have been isolated from plant and animal sources, and more will be isolated in the near future, a proper generic name is highly desirable. We urge adoption of the generic name ecdysteroids.

If a subdivision of this class of compounds to source is required, the names 'zooecdysteroids' and 'phytoccdysteroids' may be used. The generic term 'phytoecdysones' should be abandoned.

The name 'ecdysone' should only be used for the molting hormone isolated from insect sources by Butenandt and Karlson' represented by formula I, that<smiles>CC(C(O)CCC(C)(C)O)C1CCC2(O)C3CC(=O)C4CC(O)C(O)CC4(C)C3CCC12C</smiles><smiles>CC(C)(O)CCC(O)C(C)(O)C1CCC2(C)C1CCC1C3CC(O)C(O)CC34CC(O)C(O)CC4C12O</smiles>

is $2 \beta, 3 \beta, 14 \alpha, 22 \mathrm{R}, 25$-pentahydroxy$5 \beta$-cholest-7-en-6-one.

Compound (II) $2 \beta, 3 \beta, 14 \alpha, 20 \mathrm{R}, 22 \mathrm{R}$, 25 -hexahydroxy- $5 \beta$-cholest-7-en-6-one or 20-hydroxy-ecdysone, has been isolated from natural sources independently several times: as $\beta$-ecdysone $e^{2,3}$, as ecdysterone $e^{4}$, as crustecdystone ${ }^{5}$, as isoinokosterone ${ }^{6}$, and ${ }^{7}$ as polypodine A. We propose to use the term "20-hydroxyecdysone' as the name for this biologically important molecule. In the physiology of insects and crustaceans, the terms 'ecdysterone' and 'crustecdysone' may be used. The isolation from crustacean material can claim priority to all other reisolations, since the substance described as $\beta$-ecdysone was not pure 20-hydroxyecdysone. But the name '20-hydroxyecdysone' stresses the close relationship to ecdysone; this, we feel, is desirable. Yours faithfully, T. W. Goodwin

University of Liverpool, UK D. H. S. HORN

C.S.I.R.O. Melbourne, Australia P. KARISON J. KoOLMAN

University of Marburg, West Germany K. NAKANISHI

Columbia University, New York, USA W. E. RobBins

U.S. Department of Agriculture, Beltsville, Maryland, USA

J. B. Siddall

Zoecon Corporation, California, USA T. TAKEMOTO

Tokushima Bunri University, Japan

1. Butenandt, A. \& Karlson, P., Z. Naturforsch. 9b 389-391 (1954)

2. Karlson, P., Congress Internat. de Biochemie Bruxelles Abstract 12-3 (1955); Ann. Sci. Natur. Zool. 18, A25-137 (1956).

3. Hocks, P., Schulz, G., Watzke, E. \& Karlson, P.,

, Angew. Chemie 78, 269-270 (1966). Hampshire, F. \& Horn, D. H. S., Chem. Commun. $37-38(1966)$

. Takemoto, T., Ogawa, S. \& Nishimoto, N.,

. Jizba, J., Herout, V. \& Sorm, F., Tetrahedron

\section{Catastrophe theory}

SiR,-Zahler's recent letter (2 February, page 401) contains a number of misapprehensions and errors. I have no wish to prolong the correspondence on the applications of catastrophe theory so I will confine myself to correcting his misunderstanding of what $I$ said in my letter (22/29 December, page 658) about Kozak and Benham's model for protein denaturation.

My letter does not give "another reason why catastrophe theory should not apply to denaturation". It explains why protein denaturation cannot conform to the cusp catastrophe, as Kozak and Benham agree (private communication). In their later paper (J. Theor. Bio. 63, page 125), Kozak and Benham use catastrophe theory to discuss the continuous transition of protein denaturation by means of a distribution of catastrophe potential functions. 7ahler's observation that their use of the Maxwell convention "removes the cusp and thus catastrophe theory from the analysis" is correct to the extent that under the Maxwell convention the catastrophe set is a line and not a cusp. But this is irrelevant and the latter part of the quotation incorrect because the elementary catastrophes are described geometrically and do not depend on the choice of convention for determining the governing minimum of the potential

function.

University of York, UK

$$
\begin{aligned}
& \text { Yours faithfully, } \\
& \text { MAURICE Dodson }
\end{aligned}
$$

Sunflower's blooming floscule is a compass

SIR,--Two letters (8 September, page 102 and 15 December, page 556) correctly describe the behaviour of the top (and the bud) of growing sunflowers Helianthus annus. Such movements are nutational ones. (The picture with the second letter is unfortunately incorrect: they should be buds.)

I should like to add the following. When the basis of the bud (the part between the stem and the bud) becomes steep instead of smooth, these nutational movements get smaller and smaller in diapason and point less and less to the West. Finally, before blooming the floscules stop their movements completely and (for them) forever. Most parts of blooming floscules are orientated to the sunrise. In the mornings they look at the sun and so give an impression of unanimous movements after the sun. This is the only time of day when this is true.

That is why blooming (and faded) floscules of the sunflower are living compasses (however not too exact): west is behind, north to the left, and south to the right. This is true for open country. If the sunflowers are shaded by a wall from the east, their blooming floscules look (permanently) to the west side. Perhaps they need UV for seed formation, the intensity of which is the most at sunrise, least at midday and intermediate at sunset.

Another question also seems interesting. In different languages the sunflower has different meanings, for example:

- "A flower (rose etc.) of the sun" in Latin, English, Swedish, Dutch, German, Rumanian, Armenian, Buryat,

Mongolian, Kalmyk, Altaian, Latvian, Fstonian, Finnish, Afghan, Burmese, Czech, Polish. Ukranian, Byelorussian, Danish, Greek;

- "Turning after the sun", "Looking at the sun" in Spanish, Portuguese, rtalian, French, Bulgarian, Hungarian, Mordovian, Uzbek, Bashkir, Serbian, Azerbaijani, Kirghiz, Turkmen, Japanese, Chinese, Viet-Namese;

- "Under the sun" in Russian (and one of the Serbian dialects);

- "Moon flowers", "Looking at the moon" in Turkish, Karakalpak.

Unfortunately, I do not know how to translate the names of the sunflowers from (American) Indian languages: Navaho-"ntigiliitahoh". Hopi-"tcego

a gaw u" and Keres-"hi cti".

Yours faithfully,

Principality of Monaco 